\title{
Insecticide resistance and posible mechanisms of Aedes aegypti (Diptera: Culicidae) in Yogyakarta
}

\author{
Budi Mulyaningsih ${ }^{1 *}$, Sitti Rahmah Umniyati ${ }^{1}$, Tri Baskoro Tunggul Satoto ${ }^{1}$, Ajib \\ Diptyanusa', Dwi Aris Agung Nugrahaningsih'2 ${ }^{2}$ Yahiddin Selian ${ }^{3}$ \\ 'Department of Parasitology, ${ }^{2}$ Department of Pharmacology and Therapy, Faculty of \\ Medicine, Universitas Gadjah Mada, Yogyakarta, ${ }^{3}$ Ministry of Health, Sub-directorate of \\ Vector Control, Jakarta, Indonesia
}

DOI: http://dx.doi.org/10.19106/JMedSci005001201803

\begin{abstract}
For several decades, applications of malathion and cypermethrin insecticides have been extensively used to control Aedes aegypti. Hence it is important to study mosquito vector resistance status and its posible mechanisms in relation to long term use of insecticides. This study aimed to determine the resistance status and to characterize mechanisms of Ae. aegypti to malathion and cypermethrin. Larvae and puppae of Ae. aegypti were collected in the field of Plosokuning, Minomartani, Sleman, Yogyakarta Special Region, Indonesia. The biological assay was carried out using CDC Bottle Bioassay to test the resistant status. The biochemical assay was conducted using microplate assay with substrate $\alpha$-naphthyl acetate to test the presence of esterase elevated activity. The molecular assay was done using PCR with primers AaSCF1 and AaSCR4 to detect of point mutation at S989P, I1011M (or V), L1014F sites, and AaSCF7 and AaSCR7 to detect of point mutation at $\mathrm{F} 1534 \mathrm{C}$ site. The biological assay showed Ae. aegypti suggests the possibility of resistance to malathion with $82 \%$ mortality $(246 / 300)$ and already resistant to cypermethrin with $76 \%$ mortality (228/300). The biochemical assay of Ae. aegypti showed the presence of non-specific esterase elevated activity. The PCR method using AaSCF1 and AaSCR4 primers did not show specific DNA bands with the size of $619 \mathrm{bp}$. However using AaSCF7 and AaSCR7 primers showed specific DNA bands with the size of 748bp. Voltage gated sodium channel gene sequencing compare with Gene Bank (AB914687 and AB914688) showed that there was no changes on the 1534 site. Long term use of insecticides did not successfully eliminate the targeted dengue vector, because $A e$. aegypti were resistant to both insecticides. The results demonstrate the importance of designing better health policies regarding insecticide usage.
\end{abstract}

\section{ABSTRAK}

Dalam beberapa dekade, penggunaan insektisida malation dan sipermetrin sangat luas untuk pengendalian nyamuk Aedes aegypti. Oleh sebab itu penting untuk mempelajari status resistensi dan mekanisme terjadinya resistensi dalam hubungannya dengan penggunaan insektisida secara terus menerus dalam jangka waktu yang lama. Tujuan penelitian ini adalah menentukan status resistensi Ae. aegypti terhadap insektisida malation dan sipermetrin berserta mekanismenya. Larva dan pupa Ae. aegypti dikoleksi dari daerah Plosokuning, Minomartani, Sleman, Daerah Isttimewa Yogyakarta, Indonesia. Bioasai dilakukan dengan metode CDC Bottle Bioassay, metode biokhemis dilakukan

\footnotetext{
${ }^{*}$ corresponding author : budi.mulyaningsih@ugm.ac.id
} 
dengan microplate assay dengan substrat $\alpha$-naphthyl asetat. Metode penetapan molekular digunakan PCR dengan primer AaSCF1 and AaSCR4 untuk deteksi mutasi pada titik S989P, I1011M (atau V) dan L1014F adapun primer AaSCF7 dan AaSCR7 untuk deteksi mutasi pada titik F1354C. Hasil bioasai menunjukkan Ae. aegypti sudah resisten terhadap malation dengan mortalitas $82 \%$ (246/300) dan sudah resisten terhadap sipermetrin dengan mortalitas $76 \%$ (228/300). Dengan metoda biokhemis menunjukkan terjadi peningkatan aktivitas enzim esterase non spesifik. Pada metoda PCR dengan primer AaSCF1 and AaSCR4 tidak muncul pita DNA spesifik dengan ukuran 619bp, tetapi dengan primer AaSCF7 dan AaSCR7 muncul pita spesifik dengan ukuran 748bp. Hasil sekuensing gene voltage gated sodium chanel dibandingkan dengan Gen Bank (AB914687 dan AB914688) menunjukkan tidak ada mutasi pada pada titik 1354. Penggunaan insektisida dalam jangka waktu yang lama tidak berhasil mengeleminasi vektor dengue oleh karena Ae. aegypti resistan terhadap kedua insektisida tersebut. Hasil penelitian ini menunjukkan bahwa perlu dirancang kebijakan kesehatan yang lebih baik dalam penggunaan insektisida.

Keywords: malathion - cypermethrin - biological assay - biochemical assay - molecular assay

\section{INTRODUCTION}

Dengue is a mosquito-borne infection that in recent decades has become a major international public health concern. Aedes aegypti, Linnaeus (Diptera: Culicidae), is the primary vector of dengue and plays the most central role in transmitting dengue as they have a high affinity to humans. ${ }^{1}$ Dengue virus is found in tropical and sub-tropical regions around the world, predominantly in urban and semi-urban areas. The worldwide cases of dengue fever have increased substantially in recent years with more than one-third of the world's population living in areas at risk for infection. ${ }^{2}$ One recent study documents 390 million dengue infections each year, of which 96 million manifest clinically. ${ }^{3}$ According to data from the Health Ministry of Republic of Indonesia, from January to July 2013, 50,417 dengue fever cases recorded in Indonesia, with mortality rates reaching $0.75 \%$ amounting to 380 deaths. ${ }^{4}$ In 2013, Yogyakarta Special Region was in the top 3 of the areas with greatest incidence rate of dengue with cases of 95.99 per 100,000 people. $^{5}$ The main vector for dengue disease in Indonesia is Ae. aegypti.
Its close relative, Ae. albopictus Skuse, is also involved in dengue transmission as a secondary vector. ${ }^{6}$

Insecticide resistance is an inherited characteristic involving changes in one or more insect gene and one feature of the evolution of insecticide resistance in the field that recurs through all the pre-genomic and genomic studies is the rapid spread of resistance alleles after the initial outbreak. ${ }^{7,8}$ The majority of cases of insecticide resistance are either based on increased metabolic detoxification or reduction in the sensitivity of the insecticide's target site to inhibition. The target site for organophosphate insecticides is acetylcholine esterase which can be altered to a form that is less sensitive to insecticide inhibition. The target sites for pyrethroids are the ion channels of the nerve membrane, and resistance in some species is dependent on a change in binding affinities of insecticides to the sodium channels of the nerve membrane, i.e voltage-gated sodium channel (VGSC). ${ }^{9-10}$ Several different point mutations within the VGSC gene contribute to such resistance and occurrences of VGSC gene mutations were 
reported in agricultural and health threatening insects. Several mutations in segment 6 of domain II of the VGSC were reported to play important roles in pyrethroids resistance of Ae. aegypti (I1011M, I1011V, V1016G and $\mathrm{V} 1016 \mathrm{I}) .{ }^{10-12}$ Yanola et al. $^{13,14}$ identified a novel F1534C mutation in segment 6 of domain III in DDT or permethrin-resistant Ae. aegypti. Harris et al. ${ }^{15}$ reported that the $\mathrm{F} 1534 \mathrm{C}$ mutation is strongly correlated with resistanc to DDT and pyrethroid. The S989P mutation in domain II of the voltage-gated sodium channel gene, which occurs in deltamethrinresistant $A$ e. aegypti, is another principal kdr mutation that regulates pyrethroid resistance in mosquitoes. ${ }^{16}$

In Yogyakarta Special Region, the organophosphate insecticides have been used since 1974, and pyrethroids has also been used since 10 years ago. ${ }^{17}$ Previous studies showed the resistance towards organophosphate and pyrethroids insecticide in most part of Central Java and Yogyakarta Special Region. ${ }^{18,19}$ However, long term use of insecticides can lead to development of resistance, and the mechanisms of resistance have not been studied, yet. The study aimed to evaluate the status of dengue vector resistance and its mechanisms in relation to long term used of insecticides in order to develop better health policies for disease control.

\section{MATERIALS AND METHODS}

\section{Subjects}

Larvae and puppae of Ae. aegypti were collected in the field from Plosokuning, one of the dengue endemic areas in Sleman District, Yogyakarta Special Region, Indonesia in December 2015. The collected larvae (263) and pupae (52) were colonized in the laboratory of Parasitology, Department of Parasitology, Faculty of Medicine, Universitas Gadjah
Mada, Yogyakarta, Indonesia to get adult stage. The adult mosquitoes were identified to confirm the presence of Ae. aegypti. The mosquitoes were maintained at $25 \pm 2{ }^{\circ} \mathrm{C}$, $80 \%$ relative humidity, with a photoperiod of $12 \mathrm{~h}$ of artificial daylight and $12 \mathrm{~h}$ of darkness and a $10 \%$ sucrose solution as mosquito feed. Colonization of the mosquitoes was continued 2 times until there were sufficient number of Ae. aegypti. The same methods of colonization were also applied to mosquitoes of the laboratory of Parasitology collection as positive and negative control. The positive control was F 102, highly resistant (RR) to malathion and the mortalities were $52 \%$. The negative control was F 1112, highly susceptible (SS) to malathion and the mortalities were $100 \%$. Mosquitoes were sorted by sex and species, and only females 2-6 days old were used. Mosquitoes fed only with 10\% sugar water solution were subjected to all series of biological, biochemical and molecular assays.

\section{Experimental and analysis}

The biological assays followed the procedures for the CDC Bottle Bioassay using adult female mosquitoes. Two insecticides were used for bioassay, malathion (DREXEL, France) and cypermethrin (CYNOFF, FMC USA), after dissolving in acetone. According to this method, the diagnostic dose of malathion was $50 \mu \mathrm{g} /$ bottle, and cypermethrin was $10 \mu \mathrm{g} /$ bottle, whereas diagnostic time of malathion and cypermethrin were $30 \mathrm{~min}$. Sample size was 100 mosquitoes for the initial test and 25 mosquitoes for the negative control as discribed by CDC. ${ }^{20}$ In this test, the number of the mosquitoes that had been examined was 300 for initial test and 75 for negative control. All of the assay was conducted in triplicated.

The presence of esterase elevated activity, associated with organophosphate resistance, was confirmed by biochemical tests, and it was 
conducted by microplate assay as discribed by $\mathrm{Lee}^{21}$ and also apllied by Mardihusodo. ${ }^{22}$ In this method were used $\alpha$-naphthyl acetate (Sigma) as substrate; Fast Blue B salt (Sigma) in sodium dodecyl sulphat (Sigma) solution as coupling reagent. The whole body of individual mosquito was used for all experiments. A singgle mosquito was homogenized in $0.5 \mathrm{~mL}$ PBS using a pellet pestle. With a micropipette, $50 \mu \mathrm{L}$ of the homogenate was transferred to each well on microplate 96 wells. Fifty $\mu \mathrm{L}$ of substrate solution freshly prepared were then pipetted into each well and left for $60 \mathrm{sec}$ and $50 \mu \mathrm{L}$ of coupling reagent was then added. Immediately the color of solution in the wells developed which turned to blue after standing for $10 \mathrm{~min}$. The reaction was stopped by the addition of $50 \mu \mathrm{L} 10 \%$ acetic acid into each well. The intensity of the color of reaction indicating of esterase activity of Ae. aegypti mosquitoes. The color could be differenciated by eye score and by detecting the absorbance value (AV) using microplate reader (BIORAD microplate Reader Benchmark) at $\lambda 450 \mathrm{~nm} \cdot{ }^{23}$ The number of the mosquitoes that had been examined was 48 and its were replicated 3 times. Non-specific esterase activity of positive and negative control values were used as a standard. The interpretation of the results was AV $<0.700$ as highly susceptible (SS), $\mathrm{AV}=0.700-0.900$ as moderately resistant (RS) and AV $>0.900$ as highly resistant (RR). ${ }^{24}$ Average AV was also analyzed based on cut off positive value, calculated from the average AV of negative control $+2 \mathrm{SD}$ (standard deviation). ${ }^{23}$

Molecular methods were carried out to determine the VGSC by using PCR. The mosquito samples were lightly dried on a paper towel and placed in a $1.5-\mathrm{mL}$ PCR reaction tube, 10 mosquitoes per tube (pooling). The sample was homogenized in a mixed solution of extraction solution
(40 $\mathrm{mL}$ ) plus tissue-preparation solution $(10 \mathrm{~mL})$ (REDExtract-N-Amp Tissue PCR Kit; Sigma, St. Louis, MO) for extraction of DNA. The solution was heated at $95{ }^{\circ} \mathrm{C}$ for 3 min and neutralized. Initial amplification was carried out using the primers AaSCF1 (AGACAATGTGGATCGCTTCC) and AaSCR4 (GGACGCAATCTGGCTTGTTA) to test for the present of point mutation at S989P, I1011M (or V), L1014F and V1016G (or I) all of which are located in the area of segment 6 of domain II; and primers AaSCF7 (GAGAACTCGCCGATGAACTT) and AaSCR7 (GACGACGAAATCGAACAGGT) to test for the present of point mutation at F1534C located in the area of segment 6 of domain III (Integrated Dna Technology). The PCR mixture contained $4 \mathrm{ml}$ of REDExtractN-Amp ReadyMix (Sigma), $0.5 \mathrm{mM}$ of each primer, and $1 \mathrm{~mL}$ of the DNA template in a total volume of $10 \mathrm{~mL}$. The PCR was performed under the following conditions initial denaturation at $94^{\circ} \mathrm{C}$ for $3 \mathrm{~min} ; 35$ cycles each of $94{ }^{\circ} \mathrm{C}$ for $15 \mathrm{sec}, 55{ }^{\circ} \mathrm{C}$ for $30 \mathrm{sec}$, and $72{ }^{\circ} \mathrm{C}$ for $30 \mathrm{sec}$ and a final elongation step at $72{ }^{\circ} \mathrm{C}$ for $10 \mathrm{~min}$. The amplified fragments of the expected size were purified with ExoSAPIT (USB Corporation, Cleveland, $\mathrm{OH}$ ) at 37 ${ }^{\circ} \mathrm{C}$ for $30 \mathrm{~min}$, and then $80{ }^{\circ} \mathrm{C}$ for $15 \mathrm{~min} .{ }^{25}$ Electrophoresis was performed using 2\% agarose and followed by examination under ultraviolet light. The DNA sequencing was carried out by First Base Laboratories, to indentified point mutation at S989P, I1011M (or V), L1014F and V1016G (or I) (accession No. AB914689 and AB914690) and point mutation at $\mathrm{F} 1534 \mathrm{C}$ point mutation (accession No. AB914687 and AB914688). This study has been approved by the Medical and Health Research Ethics Committee, Faculty of Medicine, Universitas Gadjah Mada, Yogyakarta. 


\section{RESULTS}

The results of bioassay with malathion (organophosphate) and cypermethrin (pyrethroids) insecticides at the CDC diagnostic dose and its diagnostic time for Ae. aegypti adult mosquitoes are shown in TABLE 1 . The following criteria was used for interpretation of adult susceptibility test as recommended by World Health Organization (WHO),
98-100\% mortality indicates susceptibility, $80-97 \%$ mortality suggests the possibility of resistance that needs to be further confirmed and $<80 \%$ mortality suggests resistance..$^{25}$ According to WHO's recommendation, Ae. aegypti from Plosokuning, Minomartani, Sleman, Yogyakarta Special Region was resistant to malathion with $82 \%$ mortality but need to be further confirmed, and resistant to cypermethrin with $76 \%$ mortality.

TABLE 1. Percentage mortalities in the CDC bottle bioassay of adult female of Ae. aegypti for evaluating insecticide resistance to diagnostic dose and diagnostic time of malathion and cypermethrin

\begin{tabular}{cccc}
\hline Variable & $\begin{array}{c}\text { Malathion } \\
(\mathbf{5 0 u g} / \mathbf{b o t t l e}, \mathbf{3 0} \mathbf{~ m i n})\end{array}$ & $\begin{array}{c}\text { Cypermethrin } \\
(\mathbf{1 0} \mathbf{~ u g} / \mathbf{b o t t l e}, \mathbf{3 0} \mathbf{~ m i n})\end{array}$ & Control acetone \\
\hline Mosquitoes mortality $(\%)$ & $82(246 / 300)$ & $76(228 / 300)$ & $0(0 / 75)$ \\
\hline
\end{tabular}

A total of 48 adult stage specimens of $A e$. aegypti were assayed for activity of esterase with 20 adult stage species of Ae. albopictus (laboratory strain) as negative control and 20 adult stage species of $A$. togoi (laboratory strain) as positive control. TABLE 2 shows interpretation on the absorbance value (AV) of Ae. aegypti adult stage specimens due to esterase elevated activity in hydrolyzing $\alpha$-naphtyl acetate.

TABLE 2. Potential resistance to insecticides of Ae. aegypti based on the average absorbance value (AV) of non-specific esterase activity

\begin{tabular}{lccc}
\hline \multirow{2}{*}{ Variable } & \multicolumn{3}{c}{$\%$ of the resistance status } \\
\cline { 2 - 4 } & $\mathbf{A V}<\mathbf{0 . 7 0 0}(\mathbf{S S})$ & $\mathbf{A V}=\mathbf{0 . 7 0 0 - 0 . 9 0 0}(\mathbf{R S})$ & $\mathbf{A V}>\mathbf{0 . 9 0 0}(\mathbf{R R})$ \\
\hline $\begin{array}{l}\text { The absorbance value of non- } \\
\text { specific esterase activity }\end{array}$ & $75.70(109 / 144)$ & $24.30(35 / 144)$ & $0.00(0 / 144)$ \\
\hline
\end{tabular}

$\mathrm{SS}=$ susceptible, $\mathrm{RS}=$ moderatly resistant, $\mathrm{RR}=$ highly resistant

The potential resistance (moderatly resistant) for organophosphate insecticide due to esterase elevated activities were found among Ae. aegypti mosquitoes which was $24.30 \%$ of total mosquito tested (48 samples, 144 replicate). These findings implied that the population Ae. aegypti under the study comprised at least 2 subpopulations, i.e. susceptible and resistant.
Average absorbance values (AV) of nonspecific esterase activity of Ae. aegypti, A. togoi as positive control and A. albopictus as negative control are shown TABLE 3 . According to cut off positive calculations from AV average of negative control +2 SD $(0.161$ $+(2 \times 0.089)=0.339)$, the AV of mosquitoes tested can be grouped into categories of susceptible if average $\mathrm{AV}<0.339$; moderate 
resistance if average AV $=0.339-0.498$ and high resistance if average $\mathrm{AV} \geq 0.498$. Using cut off positive calculations, adult mosquitoes of Ae. aegypti are indicated to have been moderately resistant to organophosphate insecticide.

TABLE 3. The average absorbance value of non-specific esterase activity of Ae. aegypti, Ae. togoi and Ae. albopictus

\begin{tabular}{lc}
\hline \multicolumn{1}{c}{ Mosquitoes tested } & Mean \pm SD \\
\hline Field mosquitoes tested $^{\mathrm{a}}$ & $0.354 \pm 0.125$ \\
Positive control $^{\mathrm{b}}$ & $0.498 \pm 0.164$ \\
Negative control $^{\mathrm{c}}$ & $0.161 \pm 0.089$ \\
\hline
\end{tabular}

${ }^{\mathrm{a}}$ Ae. aegypti from Plosokuning, Minomartani, Sleman; ${ }^{\mathrm{b}} \mathrm{Ae}$. togoi and ${ }^{\mathrm{c}} A$ e. albopictus from Parasitology Laboratory

Molecular methods using AaSCF1 (AGACAATGTGGATCGCTTCC) and AaSCR4 (GGACGCAATCTGGCTTGTTA) primers no amplicon were obtained, while using AaSCF7 (GAG AAC AAC ATG CCG TCG TT) and AaSCR7 (GAC GAC GAA GAA CAG ATC GT) primers amplicon were obtained from Ae. aegypti with the size 748bp (FIGURE 1).

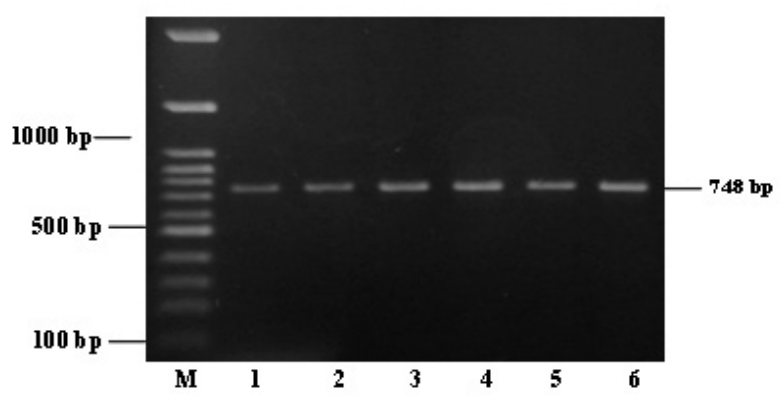

FIGURE 1. Visualization of the amplicons of approximately 748 bp corresponds to mutation gene F1534C. M = DNA Marker; 1-6 = Ae. aegypti

The results of sequencing analysis VGSC gene of $A$. aegypti with primers AaSCF7 and AaSCR7 compare with Gene Bank AB914687 and AB914688, showed that there was possible amino acid change on the 1534 site from phenylalanine (TTC) into cysteine (TGC) (FIGURE 2).

\section{Mega 6.0 \\ VGSC Gene mutation at F1534C \\ Gene Bank AB914687}

Sample 214

GTGTTCTTCATCATCTTCGGGTCGTTCTTCACGCTGAATCTGTTCATCGGTGTC

FIGURE 2. The results of sequencing analysis VGSC gene of Ae. aegypti with primers AaSCF7 and AaSCR7 compare with Gene Bank Gen Bank (AB914687 and AB914688)

\section{DISCUSSION}

Resistance of vector to insecticide has continued to spread and affect disease control in many countries. Aedes aegypti field population showed resistance to both malathion and cypermetrin insecticide, these data may provide early evidence that malathion and cypermethrin are losing their effectiveness. These results might be due to the same mechanism operationally underlying the resistance associated with enzyme activity. It is evident that this important vector species, Ae. aegypti, may allow cross-resistance of malathion (organophosphate group) and cypermethrin (pyrethroid group). Crossresistance possibly occurs in some mosquitoes, where the individual mosquito has developed resistance to two or more insecticide group. ${ }^{26}$

Non-specific esterase is well recognized as an important enzyme for detoxification of 
related chemical insecticides and one of many insecticide resistance mechanisms known to occur in mosquitoes. ${ }^{17}$ This result also revealed the presence of consistency that mosquito resistance to organophosphate and pyrethroid insecticides is directly associated with esterase elevated resistance mechanism. ${ }^{29,30}$ Most of the insecticide groups contain ester linkages which are susceptible to hydrolysis by esterase. Resistant insects usually show a very high activity of estrases..$^{30,31}$ Detoxification mechanism mediated through non-specific esterases is another major mechanism of resistance in insects. These esterases detoxify organophosphate, carbamates and synthetic pyrethroid insecticides by two main ways, hydrolysis of the ester bond and binding of the pesticide to the active site of esterase. ${ }^{32}$

After the first description of the newly identified $\mathrm{F} 1534 \mathrm{C}$ point mutation in $A e$. aegypti collected in Thailand, ${ }^{13,14}$ the same mutation was reported in Vietnam, ${ }^{31}$ Brazil, Venezuela, Madeira Island, Portugal, ${ }^{28}$ and Grand Cayman Island, UK. ${ }^{15}$ In the present study, was determined a moderate frequency of this point mutation in Yangon City. ${ }^{24}$ Additionally, the same mutation was reported in another DHF vector, Ae. albopictus, at high frequency $(73 \%) .{ }^{31}$ Elucidation of the worldwide distribution of the F1534C mutation in Ae. aegypti and Ae. albopictus will provide a valuable insight into DHF epidemiology and yield useful information for vector control programs. The development of mosquito resistance to chemical insecticides makes the control of mosquitoes and hence the diseases more difficult. ${ }^{25}$ Continuous monitoring of insecticide susceptibility in Aedes populations is critical for decisions on insecticide use. Source reduction, environmental manipulation and personal protection must be emphasized in order to reduce insecticide use and to delay the further development of organophosphate resistance.

The limitations of this study on molecular testing with PCR are the isolation of mosquito DNA in each test sample derived from 10 mosquitoes (pooling method) and no positive control and negative control. Further research on the mutation of the Ae. aegypti VGSC gene should be performed using individual mosquito samples, positive and negative controls, so that the percentage of mutations in the VGSC gene in this Ae. aegypti population can be obtained.

\section{CONCLUSION}

Based on biological, biochemical and molecular assays, Ae. aegypti mosquitoes from the village of Plosokuning, Minomartani, Sleman, Yogyakarta Special Region are resistant to both organophosphate and pyrethroid insecticides by underlying mechanisms of esterase elevated and no changes on the 1534 site from phenylalanine into cysteine. These findings also indicate the Ae. aegypti are cross-resistant to insecticides, organophosphate group and pyrethroid group. The results of this study can serve to guide the development of better health policies concerning disease control.

\section{ACKNOWLEGEMENTS}

The authors wishes to thank the Faculty of Medicine, Universitas Gadjah Mada for providing funding and infrastructure facilities for carrying out this research work. We laso would like to thank Mr. Erik Hookom as native English speaker consultan, and to $\mathrm{Mr}$. Purwono, Mrs. Kuswati and Mrs. Suprihatin for mosquitoes rearing and helping laboratory work at the Department of Parasitology, Faculty of Medicine, Public Health, and Nursing Universitas Gadjah Mada. 


\section{REFERENCES}

1. Ministry of Health $(\mathrm{MOH})$ Indonesia. Dengue haemorrhagic fever in 1968-2009. Directorate General of Disease Control and Environmental Sanitation. MOH. Buletin Jendela Epidemiologi, 2010; 2: 1-13.

2. World Health Organization (WHO). Dengue/ dengue haemorrhagic fever. http://www.who. int/csr/disease/dengue/en/. 2015. Accessed Apr 29, 2015.

3. Bhatt $\mathrm{S}$, Gething P, Brady O, Messina J, Farlow A, Moyes $\mathrm{C}$, et al. The global distribution and burden of dengue. 2013. Nature 496 (7446) 504-07.

4. Kurniawati D. Rising Number of Dengue Fever Cases in Indonesia. 2013. http://www. establishmentpost.com/rising-number-of -dengue-fever-cases-in-indonesia/. Accessed Apr 29, 2015

5. Ministry of Health $(\mathrm{MOH})$ Indonesia. A Health Profile of Indonesia 2014. Directorate General ofDisease Control and Environmental Sanitation. MOH, 2015.

6. Ministry of Health $(\mathrm{MOH})$ Indonesia. Guidance book for DHF prevention and control in Indonesia Package B. Jakarta: MOH, 1999: 1-5.

7. Hemingway J, Hawkes NJ, McCarroll L and Ranson H. 2004. Insect Biochemistry and Molecular Biology. 34 :653-665.

8. Oakeshott JG. Home I. Sutherland TD, Russel RJ. The genomics of insecticide resistance. Genome Biology20034:202. https://doi. org/10.1186/gb-2003-4-1-202

9. Mourya, D. T., Hemingway, J. and Leake C. J. Changes in enzyme titres with age in four geographical strains of Aedes aegypti and their association with insecticide resistance. Med. and Vet. Entomol. 1993; 7: 11-16.

10. Brengues C, Hawkes NJ, Chandre F, McCaroll L, Duchon S, et al. Pyrethroid and DDT crossresistance in Aedes aegypti is correlated with novel mutations in the voltage-gated sodium channel gene. 2003. Med Vet Entomol 17: 87-94.

11. Saavedra-Rodriguez K, Urdaneta-Marquez L, Rajatileka S, Moulton M, Flores AE, et al. A mutation in the voltage-gated sodium channel gene associated with pyrethroid resistance in Latin American Aedes aegypti. 2007. Insect Mol Biol 16: 785-798.

12. Chang C, Shen W-K, Wang T-T, Lin Y-H, Hsu E-L, et al. A novel amino acid substitution in a voltage-gated sodium channel is associated with knockdown resistance to permethrin in Aedes aegypti. 2009. Insect Biochem Mol Biol 39: 272-278.

13. Yanola J, Somboon P, Prapanthadara L. A novel point mutation in the Aedes aegypti voltage-gated sodium channel gene associated with permethrin resistance. 2008. The 2nd International Conference on Dengue and Dengue Haemorhagic Fever, Oct. 15-17, 2008, Phuket, Thailand.

14. Yanola J, Somboon P, Walton C, Nachaiwieng W, Somwang P, et al. High-throughput assays for detection of the F1534C mutation in the voltage gated sodium channel gene in permethrin-resistant Aedes aegypti and the distribution of this mutation throughout Thailand. 2011. Trop Med Int Health 16: 501-9.

15. Harris AF, Rajatileka S, Ranson H. Pyrethroid resistance in Aedes aegypti from Grand Cayman. 2010. Am J Trop Med Hyg 83: $277-$ 284.

16. Srisawat R, Komalamisra N, Eshita Y, Zheng $\mathrm{M}$, Ono K, et al. Point mutations in domain II of the voltage-gated sodium channel gene in deltamethrin-resistant Aedes aegypti (Diptera: Culicidae). 2010. Appl Entomol Zool 45: 275-282

17. Mardihusodo SJ. Application of non-specific esterase enzyme microassays to detect potential insecticide resistance of Aedes 
aegypti adults in Yogyakarta, Indonesia. Berkala Ilmu Kedokteran. 1995; 28(4) 16771.

18. Boewono DT, Widiarti. Susceptibility of Dengue Hemorrhagic Fever Vector (Aedes aegypti) Against Organophosphate Insecticide (Malathion and Temephos) in some Districts of Yogyakarta and Central Java Province. Buletin Penelitian Kesehatan 2007; 35(2) 4956.

19. Widiarti, Heriyanti B, Boewono DT, Mujiono UW, Lasmiati, Yuliadi. Peta Resistensi Vektor Demam Berdarah Dengue Aedes aegypti Terhadap Insektisida Kelompok Organofosfat, Karbamat dan Pyrethroid di Propinsi Jawa Tengah dan Daerah Istimewa Yogyakarta. Buletin Penelitian Kesehatan 2011; 39 (4) 176-89.

20. Center for Diseases Control. Guideline for Evaluating Insecticide Resistance in Vectors using the CDC Bottle Bioassay. 2010. Available from: http://www.cdc.gov/malaria. Accessed September 9, 2014

21. Lee, H.L. Esterase Activities and Temephos Susceptibility in Aedes aegypti (L) Larvae. Mosq-Borne Dis Bull. 1990; 8: 91-94.

22. Mardihusodo SJ. Microplate assay analysis of potentialfor organophosphate insecticide resistancein Aedes aegypti in the Yogyakarta Municipality, Indonesia. Berkala Ilmu Kedokteran. 1995; 27(2) 71-9.

23. Mulyaningsih, B. Variation in Susceptibility Status to Organophosphate Insecticide among Several Geographic Populations of Aedes albopictus Skuse in Indonesia. Berkala Ilmu Kedokteran. 2004; 36 (2) 77-81

24. WHO. Report of the WHO Informal Consultation: Test procedures for insecticide monitoring in malaria vectors, bio-efficacy and persistence of insecticide on treated surfaces. 1998. World Health Organization, Geneva, Switzerland (28-30 September 1998).
25. Kawada, H., Sai, Z.M.O., Sein, T., Emiko, K., Yan, N.M.M., Hlaing, M.T., Kyaw, Z.T., Noboru, M. Co-occurrence of Point Mutations in the Voltage-Gated Sodium Channel of Pyrethroid-Resistant Aedes aegypti Populations in Myanmar. Neglected Tropical Diseases. 2014; 8 (7) e3032. doi:10.1371/journal.pntd.0003032

26. Gubler DJ. Dengue and Dengue hemorrhagica Fever. Clinical Microbiology Reviews. 1998: 408-96. July 1998, p. 480-496

27. Polson KA, Rawlins SC, Brogdon WG, Chadee DD. Characterisation of DDT and Pyrethroid Resistance in Trinidad and Tobago Populations of Aedes aegypti. Bulletin of Entomological Research. 2011; 101: 435441.

28. WHO. Monitoring of Insecticide Risistance in Malaria Vectors. 2006. http://www. emro.who.int/rbm/Publications/Insecticide Resistance. Accessed 29 Apr 2015

29. Seixas G, Salgueiro P, Silva AC, Campos M, Spenassatto C, et al. Aedes aegypti on Madeira Island (Portugal): genetic variation of a recently introduced dengue vector. Mem Inst Oswaldo Cruz 108 Suppl. 2013; 1: 3-10.

30. Kasai S, Ng LC, Lam-Phua SG, Tang CS, Itokawa $\mathrm{K}$, et al. First detection of a putative knockdown resistance gene in major mosquito vector, Aedes albopictus. Jpn J Infect Dis. 2011; 64: 217-21.

31. Crow JA, Potter PM, Borazjani A, Ross MK. Hydrolysis of pyrethroids by human and rate tissues: examination of intestinal, liver and serum Carboxylesterase. Toxicology and Applied Pharmacology. 2007; 221:1-12

32. Kawada H, Higa Y, Komagata O, Kasai S, Tomita T, et al. Widespread distribution of a newly found point mutation in voltage-gated sodium channel in pyrethroid-resistant Aedes aegypti populations in Vietnam. PLoS Negl Trop Dis. 2009; 3: e527. 